18. Gray, I.P., Siddle, K., Docherty, K., Frank, B.H. \& Hales, C.N. Proinsulin in human serum: problems in measurement and interpretation. Clin Endocrinol 1984, 21: 43-47.

19. Clark, P.M.S. \& Hales, C.N. Assay of insulin: In: Williams, G. \& Pickup, J. (eds) Textbook of Diabetes. Oxford, Blackwell Scientific, 1991, pp. 335-347.

20. Service, F.J. Hypoglycemia. Endocrinol Metabolism Clinics North Am 1988, 17: 601-616.

21. Hale, P.J., Djurup, R., Baddeley, R.M. \& Nattrass, M. Insulin and proinsulin concentrations in patients with insulinoma before and after surgical treatment. Diabetes Nutr Metab 1991, 4: 113-116.
22. Williams, D.D.R., Byrne, C., Clark, P.M.S. et al. Raised proinsulin concentration as early indicator of beta cell dysfunction. Br Med J 1991, 303: 95-96.

23. Peavy, D.F., Brunner, M.R., Duckworth, W.C., Hooker, C.S. \& Frank, B.H. Receptor binding and biological potency of several split forms (conversion intermediates) of human proinsulin. Studies in cultured IM-9 lymphocytes and in vivo and in vitro in rats. J Biol Chem 1985, 260: 13989-13994.

\title{
Cardiac arrest: a rare complication of pallid syncope?
}

\author{
Bola Taiwo and Alex H. Hamilton
}

General Infirmary at Leeds, Great George Street, Leeds, West Yorkshire LS1 3EX, UK

Summary: Cardiac arrest is rare in children. Breath-holding, on the other hand, is fairly common. We report a case in which one complicated the other with serious consequences. A review of the literature on the subject was undertaken.

\section{Introduction}

Pallid syncope (reflex anoxic seizure) is a fairly common childhood event that is probably underrecognized. It has been reported that $4.6-46.2 \%$ of a childhood population suffer breath-holding attacks of some form and $1 \%$ have pallid syncope, the others having the more commonly diagnosed and better understood cyanotic variety. ${ }^{1}$ Pallid syncope is distinguished by the child's obvious pallor during the attack, together with other signs suggestive of vagal overactivity. In a small number of patients with very frequent attacks, treatment with atropine has been shown to be effective. ${ }^{2}$

The diagnosis can be further established by the demonstration of vagal asystole from eyeball compression, a procedure said to be safe and free of complications, the cardiac standstill being selflimiting. ${ }^{3}$

These events are often very dramatic and frightening to the parents, but fundamentally harmless; we report the case of a child with a previous history of attacks suggestive of pallid syncope, who suffered an unexplained cardiac arrest.

Correspondence: B. Taiwo, F.R.C.S., Department of Surgery, Hemel Hempstead General Hospital, Hillfield Road, Hemel Hempstead, Herts HP2 4AD, UK.

Accepted: 22 February 1993

\section{Case report}

A 21 month old child had been entirely well in the past. He had a history of frequent episodes of breath-holding, starting at the age of about $6 \%$ months, during which he is said to have become $\stackrel{\varnothing}{\circ}$ profoundly pale and his parents report having been $\overrightarrow{\overrightarrow{0}}$ deeply alarmed by these in the past, although no 3 hospital contact had resulted. The patient is the $\bar{T}$ only child of the couple, neither of whom has a family history of breath-holding or sudden infant death syndrome.

On the occasion of his admission, he is said to have been well. His parents reported that they had had an argument during the early evening and a training shoe was thrown; this accidentally struck

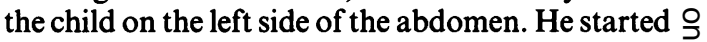
to cry, held his breath, arched his back and his eyes $\rightarrow$ rolled upwards. His father picked him up, only for him to become pale and limp.

One parent began mouth-to-mouth resuscitation of whilst the other called an ambulance. The $\tilde{N}$ paramedically trained crew arrived 4 minutes later $\underset{\omega}{N}$ and found him in asystole. He was intubated and ${ }^{2}$ cardiopulmonary resuscitation was commenced in 0 the ambulance en route to hospital; atropine and $\Phi$ adrenaline were given via the endotracheal tube $\stackrel{\odot}{+}$ without success. The accident and emergency $\square$ department was reached 25 minutes after the first call. 
Here he was found to be still in asystole with fixed dilated pupils. Intermittent positive pressure ventilation was commenced and venous access established. External cardiac massage was continued. He was given $1 \mathrm{ml} \mathrm{1/100} \mathrm{adrenaline,} 2.5 \mathrm{ml}$ $10 \%$ calcium gluconate and $20 \mathrm{ml} 8.4 \%$ sodium bicarbonate intravenously. Complexes were seen on the monitor after 10 minutes of resuscitation and a detectable cardiac output after 15 minutes. All told, he was without cerebral circulation for at least $\mathbf{4 0}$ minutes.

As his circulation improved, pupil responses returned, but remained sluggish. General examination revealed no external signs of injury and no fundal haemorrhages. His abdomen was markedly distended and when this did not improve with gastric aspiration via a naso-gastric tube a peritoneal drain was inserted; clear fluid only was obtained, however, with no blood, so this was removed.

He was subsequently transferred to the paediatric intensive care unit where he was successfully weaned from the ventilator after 48 hours and moved to the paediatric ward. A cranial computed tomographic scan performed on the third and tenth days was normal and an initial electroencephalogram showed slow wave activity only. X-rays of the cervical spine were normal.

Within the first 24 hours after admission he began to have generalized convulsions which became a severe intractable problem over the next 16 days requiring treatment with combinations of phenobarbitone, clonazepam, diazepam, paraldehyde, phenytoin, chlormethiazole and sodium valproate. They are presently well controlled on sodium valproate alone.

He has proved to have a severe spastic quadraparesis requiring nasogastric feeding. $\mathrm{He}$ is thought to be visually aware but limited by an ophthalmoplegia. His hearing is still under assessment. The long process of rehabilitation with his family is under way.

Further investigation of the possible aetiology of this child's cardiac arrest was undertaken. Eyeball compression under electrocardiogram control caused slowing from a heart rate of 140 /minute to $60 /$ minute, with immediate recovery and no arrhythmia. It was not possible to reproduce the asystole.

The electrocardiogram revealed a normal tracing with a normal corrected Q-T interval. Echocardiography was also normal.

\section{Discussion}

Sudden cardiac death from arrhythmias is known to occur as a complication of the hereditary syndromes of Q-T prolongation, such as those described by Romano, ${ }^{4}$ Ward $^{5}$ and Garza. ${ }^{6}$ The possible role of the different mechanisms of apnoea in the sudden infant death syndrome has been addressed. ${ }^{7}$ Futher research is needed to break their deadly association. In this case, however, the cardiac findings were normal and the Q-T interval within the normal range.

The circumstances of the events at home are rather bizarre and the possibility of non-accidental injury has been considered. There were no clinical findings to support this, however, and social service discussion had uncovered no new information.

The breath-holding attacks in the past are entirely compatible with pallid syncope and it is possible that the cardiac arrest in this unusual and tragic case was the result of massive vagal blockade. It is unlikely, however, that further detailed investigations in order to establish this can be ethically justified.

\section{References}

1. Lombrose, C.T. \& Lerman, P. Breath holding spells (cyanotic and pallid infantile syncope). Pediatrics 1967, 39: 563-581.

2. McWilliam, R.C. \& Stephenson, J.B.P. Atropine treatment of reflex anoxic seizures. Arch Dis Child 1984, 59: 473-495.

3. Stephenson, J.B.P. Reflex anoxic seizures and ocular compression. Dev Med Child Neurol 1980, 22: 380-386.

4. Romano, C., Gemme, G. \& Pongiglione, R. Aritmie cardiache rare dell'eta pediatrica: II, Accesi sincopali per fibrillazione ventricolare parossistica (presentazione del primo caso della letteratura pediatrica italiana). Clin Pediat 1963, 45: 656.
5. Ward, O.C. A new familial cardiac syndrome in children. $J$ Irish Med Assoc 1964, 54: 103.

6. Garza, L.A., Vick, R.L., Nora, J.J. \& McNamara, M.D. Heritable Q-T prolongation without deafness. Circulation 1970, 41: 39-48.

7. Southall, D.P. Role of apnoea in the sudden infant death syndrome. A personal view. Pediatrics 1988, 80: 73-84. 